\title{
DESIGN AND FABRICATION OF MODULAR FIXTURE FOR CMM INSPECTION
}

\author{
NaveenKumar KN ${ }^{1}$, MS Aswathnarayan ${ }^{2}$ \\ ${ }^{1}$ M-Tech StudentMechanical DepartmentEPCET, Bidarahalli Bengaluru -560049 \\ ${ }^{2}$ Associate ProfessorMechanical DepartmentEPCET, Bidarahalli,Bengaluru -560049
}

\begin{abstract}
This paper is on design and fabrication of modular fixture setup relative to inspection on co-ordinate Measuring Machine proposed and planned to increase the utilization of Co-ordinate Measuring Machine with respect to inspection activity by reducing setup time. The modular fixture design will hold component of different configuration, size and shape without much efforts to locate, align and clamp the components on the fixture. The modular fixture will ensure that even though the component is of different configuration will have one time design and setup configuration which will be standardized by assembly of fixture and then on fixture setup time will be less than a minute on the machine that to only if fixture is disturbed / removed from the Coordinate Measuring Machine table. Modular fixture will reduce setup time, hence increase opportunity to utilize the machine for useful value adding inspection purpose rather than setup activity which is noted to be non value adding activity. Along with design of modular fixture standardized method of component setup strategy is provided as work instructions to ensure components are mounted same way each time and every time whenever it is in use irrespective of time and resource.
\end{abstract}

\section{INTRODUCTION}

Accurate engineering with proper planning is most important factor in any manufacture sector for component holding solutions. Fixtures and Jigs plays key role to achieve accurate components dimensions produced out the manufacturing system, Jigs and Fixture are used to rest, orient and locate distinctively and secure the component in the correct orientation relative to the machine tool each time and every time. Hence fixtures and jigs are to be designed by considering factors like machine configuration, dynamics and component configuration without which the design of fixture and jigs may not be effective and efficient. To have an optimised fixture and jigs design it is very important to know the requirement and purpose of the fixture and jigs (machining, fabrication, pressing, inspection) also it is equally important to know where and how fixture is used example:- For Grinding operation, Turning operation, Milling operation, with stress or without stress.

Once the requirement are known next step is to gather or collect information on machine table configuration like how the fixture is rested, oriented and secured on machine table, if the fixture is used on different machines gathering detail of all such machine is considered. Once machine configuration are available component configuration detail are required like datum of components with respect to operation performed, resting face, location, clamping zone, weight, shape / profile (rectangular, square, cylinder, irregular) and material (mild steel, aluminium plastic, copper, bronze etc) of the component. Then base on the detail design activity is performed.

\section{PRODUCT DESIGN AND FABRICTION PHASES}

Before product to be designed and fabricated data collection is important, Data Collection is a methodology of collecting information and details about particular subject of interest, which is all about recording or making note of information and organising the collected details to required structure. This will support to analyze the subject of interest and helps to take necessary action and conclude on the results.

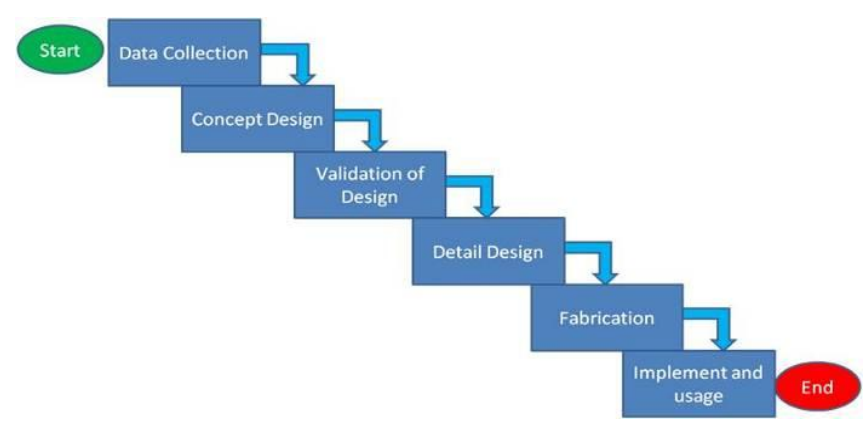

Fig 1: Product Design and Fabrication Flow Chart Above is the flow for product design and until
implementation, in which Concept Design is initial phase of
design cycle where data collected is analyzed and
requirement are decided for product function and
specification. Based on the product function and
specifications, concept designs are prepared and checked in
line with requirement. All needs should be consider during
concept design phase and also manufacturability,
serviceability and product cost should be taken into
consideration. Concept design generated will be examined
against the function and specifications listed from the
analysed data collection and best concept will be selected
for further work.
Validation is a process of testing the concept design
selected for function and specification to meeting the 
requirement. Any short fall in level will need a redesign of concept until it meets all needs. Validation of concept design is an important phase of design cycle to ensure all the product performance results are met, so concepts are finalized and further changes will be restricted due to cost and project time impact, hence validation phase play an important step in product design process which can be called as decision making phase of design cycle.

System Design is all about designing the assembly sequence of product to check all child parts are assembled together, hence product is performing the function approved at concept level. System design is to integration of all child part as a one product to meet the need. Once the System design is completed and has met the functional requirement, Product design is broken as assembly, sub assembly and child parts for which the dimension and tolerance are decided to manufacture the child parts which end the design phase of product development.

Once detail designs are made the fabrication process is designed to produce the part according to detail design. Fabrication process design will identify sequence of manufacturing processes like casting, forging, welding, brazing, turning boring and milling to bring shape to child part as per detail design. Once the fabrication of child parts is completed, child parts are assembled to meet system level design and are tested for the product function in-line with need.

Implementation phase is where the completed product will be handed over to shop to use it and the product performance will be measured and monitored. The Product in use should meet the function and specification for which it was designed and fabricated during the design and development phase. Any short fall will be taken as feedback and helps to learn and implement action for next product which will be designed and developed.

\section{DATA COLLECTION AND TIME STUDY}

Data Collection is vital part of any research or project which will give direction to work towards and obtain solution to problems. Hence at most care should be taken during performing this activity, where in minute detail will be important factor to decided the course of action, missing any detail may lead to work in wrong direction and end up with no or minimal result. Irrespective of research area data collection is very important part of any study / analysis, Hence integrity and accuracy of the data should be maintained during this activity.

\subsection{Data Collection Of Inspection}

Data collection in table is giving information on service request received and equipment utilization hours with percentage of equipment utilization for 1 year in the area where the project is being carried out, from the data collection we can conclude that Coordinate Measuring Machine is most used machine compared to any other equipment listed followed by Horizontal Metroscope. Hence doing any improvement on CMM will improve efficiency and utilization of the available facility which is objective of the project.
Based on the details of data collection, Time study was conducted on CMM inspection activity where in performing time study on CMM inspection activity will give chance to improve the utilization of CMM for more inspection time. While CMM inspection activity was carried for varies components, general activities performed were listed by observation at work place.

TABLE 1: EQUIPMENT SERVICE REQUEST DETAIL

\begin{tabular}{|l|l|l|l|l|}
\hline $\begin{array}{l}\text { Sl } \\
\text { no }\end{array}$ & $\begin{array}{l}\text { Type of } \\
\text { Equipment }\end{array}$ & $\begin{array}{l}\text { No of } \\
\text { Service }\end{array}$ & $\begin{array}{l}\text { Utlization } \\
\text { time ine in } \\
\text { hrs }\end{array}$ & $\begin{array}{l}\text { Request } \\
\text { clearance } \\
\text { in \% }\end{array}$ \\
\hline 1 & CMM & 1093 & 2190 & $39.9 \%$ \\
\hline 2 & $\begin{array}{l}\text { Roundness } \\
\text { tester }\end{array}$ & 562 & 748 & $13.6 \%$ \\
\hline 3 & Comparator & 1302 & 653 & $11.9 \%$ \\
\hline 4 & $\begin{array}{l}\text { Horizontal } \\
\text { Metroscope }\end{array}$ & 4679 & 1160 & $18.3 \%$ \\
\hline 5 & $\begin{array}{l}\text { Vertical } \\
\text { Height } \\
\text { Gauge }\end{array}$ & 1861 & 887 & $16.2 \%$ \\
\hline
\end{tabular}

TABLE 2: TIME STUDY OF CMM INSPECTION ACTIVITY

\begin{tabular}{|c|c|c|c|c|c|}
\hline $\begin{array}{l}\text { Sl } \\
\text { no }\end{array}$ & $\begin{array}{l}\text { Activity } \\
\text { involved }\end{array}$ & Category & $\begin{array}{l}\text { Avg } \\
\text { time } \\
\text { taken } \\
\text { in } \\
\text { min } \\
\end{array}$ & $\begin{array}{l}\% \text { of } \\
\text { Time }\end{array}$ & $\begin{array}{l}\text { Remark } \\
\text { S }\end{array}$ \\
\hline 1 & $\begin{array}{l}\text { Cleaning of } \\
\text { Component }\end{array}$ & $\begin{array}{l}\text { Non- } \\
\text { Value } \\
\text { added }\end{array}$ & 3.2 & 3.0 & \\
\hline 2 & $\begin{array}{l}\text { Queering of } \\
\text { component }\end{array}$ & $\begin{array}{l}\text { Value } \\
\text { added }\end{array}$ & 4.7 & 4.4 & \\
\hline 3 & $\begin{array}{l}\text { Study } \\
\text { requirement } \\
\text { for } \\
\text { inspection / } \\
\text { Calibration }\end{array}$ & $\begin{array}{l}\text { Value } \\
\text { added }\end{array}$ & 9.0 & 8.4 & \\
\hline 4 & $\begin{array}{l}\text { Planning } \\
\text { Feature for } \\
\text { inspection }\end{array}$ & $\begin{array}{l}\text { Value } \\
\text { added }\end{array}$ & 6.5 & 6.1 & \\
\hline 5 & $\begin{array}{l}\text { Setup time } \\
\text { of } \\
\text { Component }\end{array}$ & $\begin{array}{l}\text { Non- } \\
\text { Value } \\
\text { added }\end{array}$ & 27.1 & 25.3 & $\begin{array}{l}\text { Bottlene } \\
\text { ck Non- } \\
\text { Value } \\
\text { adding } \\
\text { activity }\end{array}$ \\
\hline 6 & $\begin{array}{l}\text { Inspection } \\
\text { of } \\
\text { Component }\end{array}$ & $\begin{array}{l}\text { Value } \\
\text { added }\end{array}$ & 53.3 & 49.8 & \\
\hline 7 & $\begin{array}{l}\text { Removal of } \\
\text { Component } \\
\text { from CMM }\end{array}$ & $\begin{array}{l}\text { Value } \\
\text { added }\end{array}$ & 1.8 & 1.7 & \\
\hline 8 & $\begin{array}{l}\text { Report } \\
\text { Preparation }\end{array}$ & $\begin{array}{l}\text { Value } \\
\text { added }\end{array}$ & 2.2 & 2.1 & \\
\hline
\end{tabular}

When Time study details were analyzed inspection time of component was the most time consuming activity which is a value adding activity and this was most useful activity among the list, Setup time of component was 2nd most time 
consuming activity and this was among the non-value adding activity group which needs most attention for reduction or elimination to the extent possible, 3rd most time consuming activity was input study for inspection of the component which is in the group of Value adding activity which even can be planned for reduction but not elimination.

Among the top 3 most time consuming activities, Setup time of the component is the one which is non-value adding and need to attack first for improving the availability of CMM inspection time.

The primary objective of the project is to make an attempt to reduce the setup time of Co-ordinate measuring machine for inspection purpose, Hence to optimize the utilization of Co-ordinate measuring machine to serve the demand.

Methodology used for meeting objective of project is by Modular (Single) fixture for multiple components of different configuration.

\section{CONCEPT DESIGN}

Data collection detail of inspection performed on CMM for last 1 year gives idea about number of different components received for inspection on CMM, when the data is analyzed from parto chart, Cover Clutch is the major component received with high setup time of $36.3 \%$ in the total setup time followed by crank shaft and pipe intake with $23.9 \%$ and $20 \%$ setup time.

Prato chart as shown in Fig is used for further analysis of CMM inspection data, Prato chart is also known as priority chart which consist of main data as bar graph and trend shows percentage of each component is contributing. From the Prato chart analysis theory, initiating action for first $20 \%$ of component contributing setup time will yield results of $80 \%$ reduction in setup time which is known to be $80-20$ theory.

Prato chart for CMM inspection setup time, first 3 components is contributing $80 \%$ of the setup time, hence initiating action for first 3 components to reducing or eliminating setup time will yield $80 \%$ of reduction in setup time, hence action for first 3 components should be appropriate. According to methodology discussed we need to generate concept design of modular fixture to accommodate at list first 3 components identified in Prato chart.

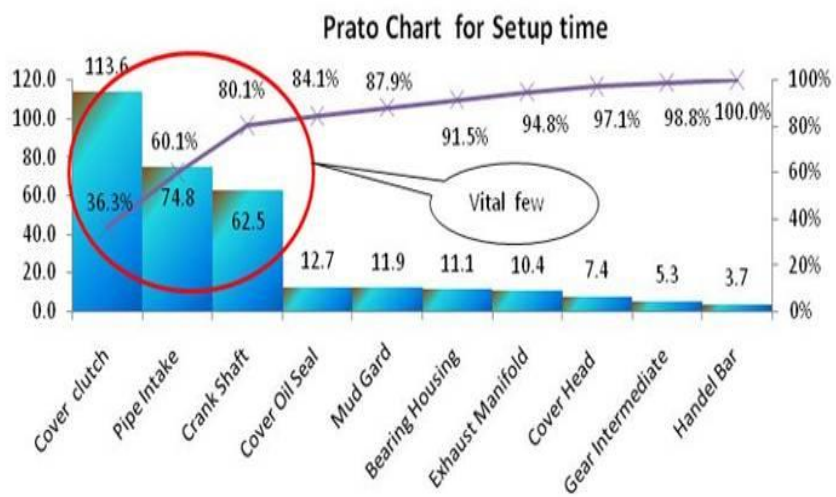

Fig 2: Prato chart for CMM inspection setup time
Cover Clutch is a first component which consists of flat face on one side, open stepped bore diameter in the middle and have mounting tapped hole for which concept design fig 3 was prepared based on the component configuration.

2nd component Pipe Intake consists of 2 flat faces on either side with 4 mounting holes on each face, 2 bore diameters on either side considering parameters above concept design looks as shown in fig 4

Crank Shaft 3rd component is a vital part of any automotive engine which converts reciprocating motion into rotary motion where in many kinematics are involved. For which concept design is shown in fig 5.
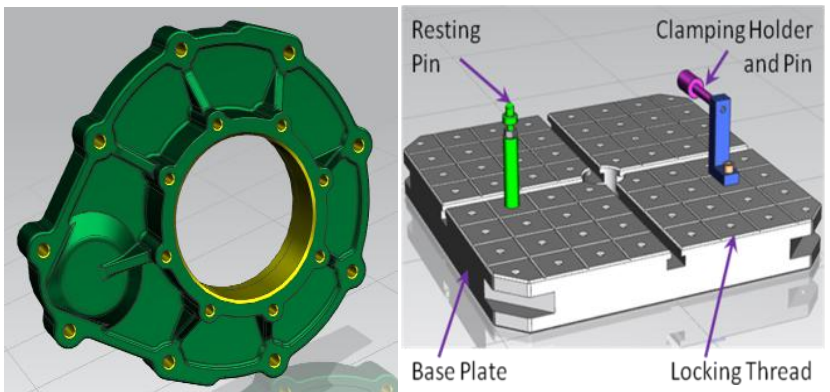

Fig 3: Concept Design for Cover Clutch Component

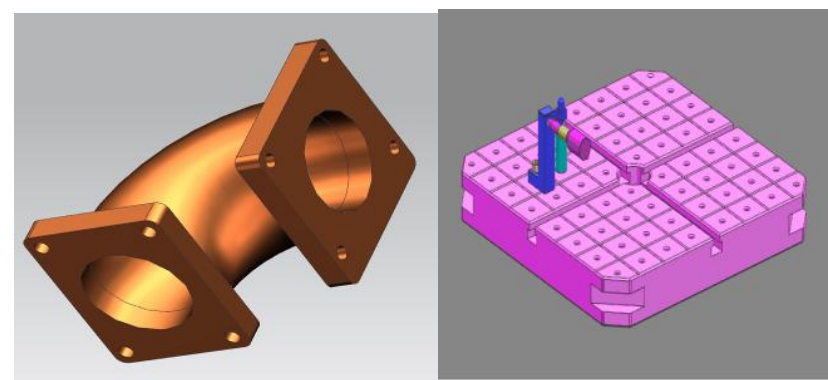

Fig 4: Concept Design for Pipe Intake Component

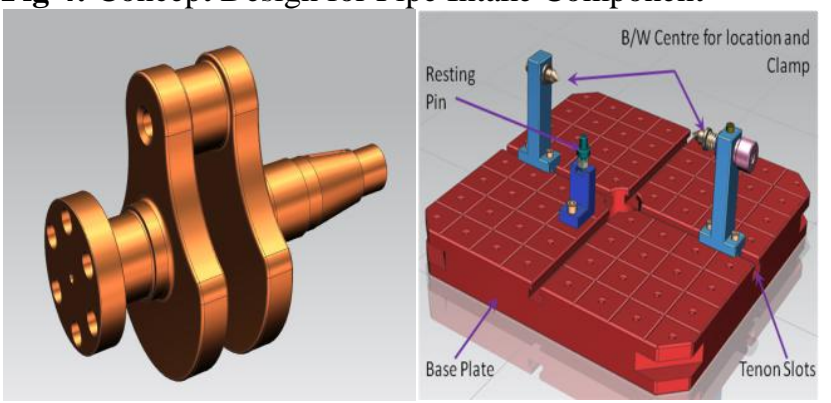

Fig 5: Concept Design for Crank Shaft Component

\section{VALIDATION OF CONCEPT DESIGN}

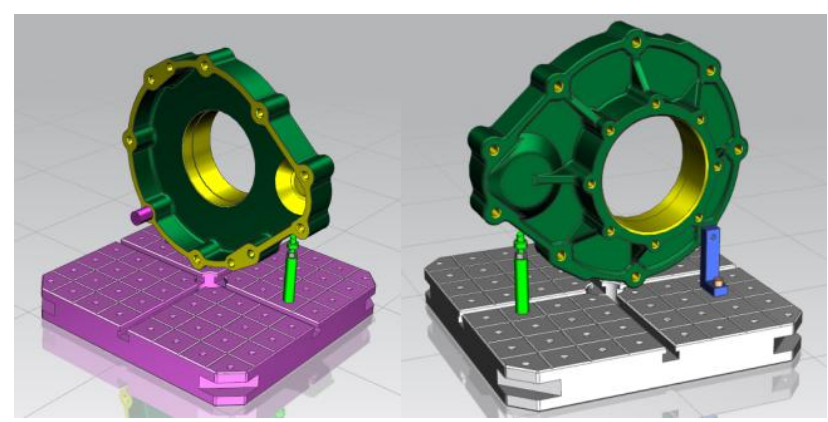

Fig 6: Validation of Cover Clutch Concept Design 
Cover clutch 3D model is assembled in to modular fixture designed for inspection in NX software to check the fit form function and the fit form function, accessibility, mounting of component and other requirements are checked to validate the concept design.

Pipe intake is assembled in to modular fixture designed for inspection in NX software to check the fit form function and the fit form function, accessibility, mounting of component and other requirements are checked.

Crank Shaft 3D model was generated and assembled on to modular fixture designed for inspection in NX software to check the fit form function, accessibility, mounting of component and other requirements.

By validation phase, concept design were frozen to continue on detail design

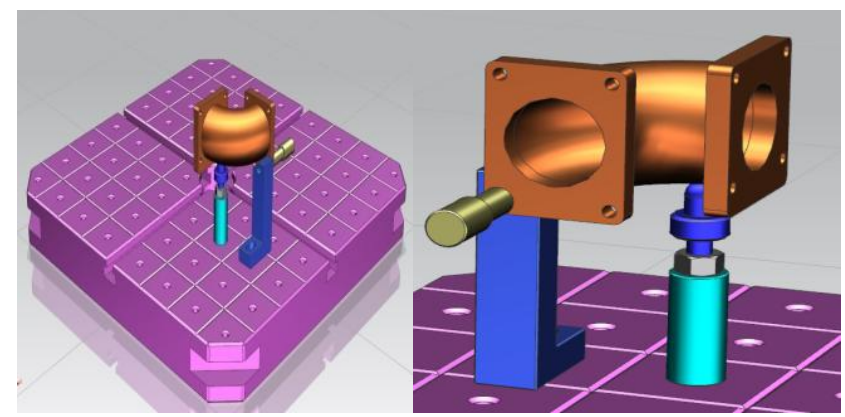

Fig 7: Validation of Pipe Intake Concept redesigned

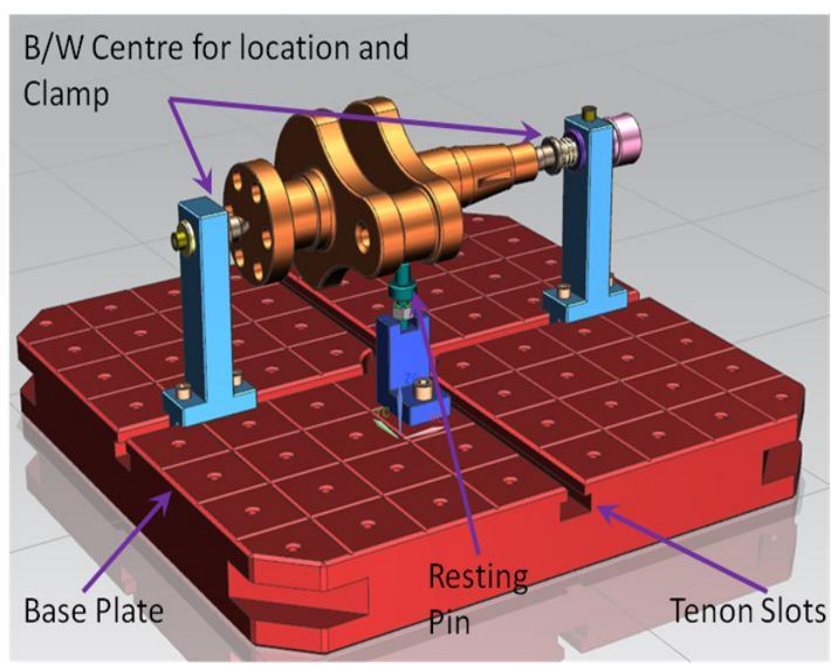

Fig 8: Validation of Crank Shaft Concept designed

\section{DETAIL DESIGN}

Details design in product development process is about transforming concept design, product architecture, design specification and technical needs of the product into detailed information from which the product can be manufactured and assembled to meet the final product functional need. Detail design explains about the technical specifications like feature dimension, tolerance to be used, datum's to be considered, material to be used, testing and acceptance criteria that product should undergo to meet the design requirement and other product and part specific information which gives details about manufacturing the product and put into end use.

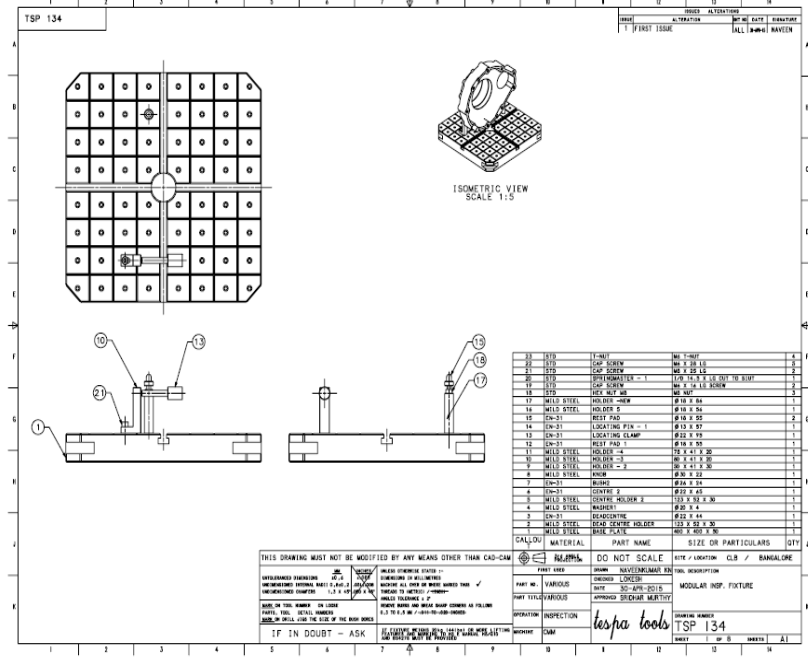

Fig 9: Detail Design Drawing Sheet 1-8

Detail generation is about creation of detailed information in terms of assembly and part drawings which will consist of all information to enable manufacturing of part which can be assembled together to make a final product.

Detail documentation is a process of generating drawing layout, and other manufacturing details of product sub assemblies and parts. During creation of design document company standards are considered to put in information which will enable clear understanding of the part level requirement to meet the end use.

Detail release is about taking a buy off of detail design generated as drawing from all the stake holders who will be involved in manufacturing part and product.

\section{FABRICATION OF FIXTURE}

Next step after detail design is to fabricate the fixture to intended detail drawings, Hence the fixture can be implemented for physical use, to fabricate the fixture it is important to conduct detail analysis on the tolerance stake up and study drawings for any other special requirement mentioned by designer with respect to fixture design and function. Process sequence of fixture setup fabrication for Crankshaft component is shown in figure PFD.

In PFD below process sequence followed for fabrication of the fixture is start with base plate of standard size MS material with required dimension is purchased and the rough milling machining process is performed to give a shape in-line with the drawing requirement, then to achieve the accuracy grinding process is performed for generating datum and reference edge followed by drilling and reaming of tooling hole which considered as reference for machining all other hole to required position, then Surface grinding is performed to achieve the flatness and width of the base plate followed by drilling of all mounting and weight reduction holes and completed with tapping and grooving process.

For dead centre holder the bar of standard size available is purchased of MS material and rough millings is performed to start with and achieve the required profile, then grinding process is finished to achieve the accuracy of tenon slide 
and reference face. Drilling and reaming operation is performed to complete the centre mounting hole and drill and tapping is done generate holder mounting hole.

Similarly all detail parts are fabricated and finally assemblies of all detail components are completed to have fixture for inspection of crank shaft component.

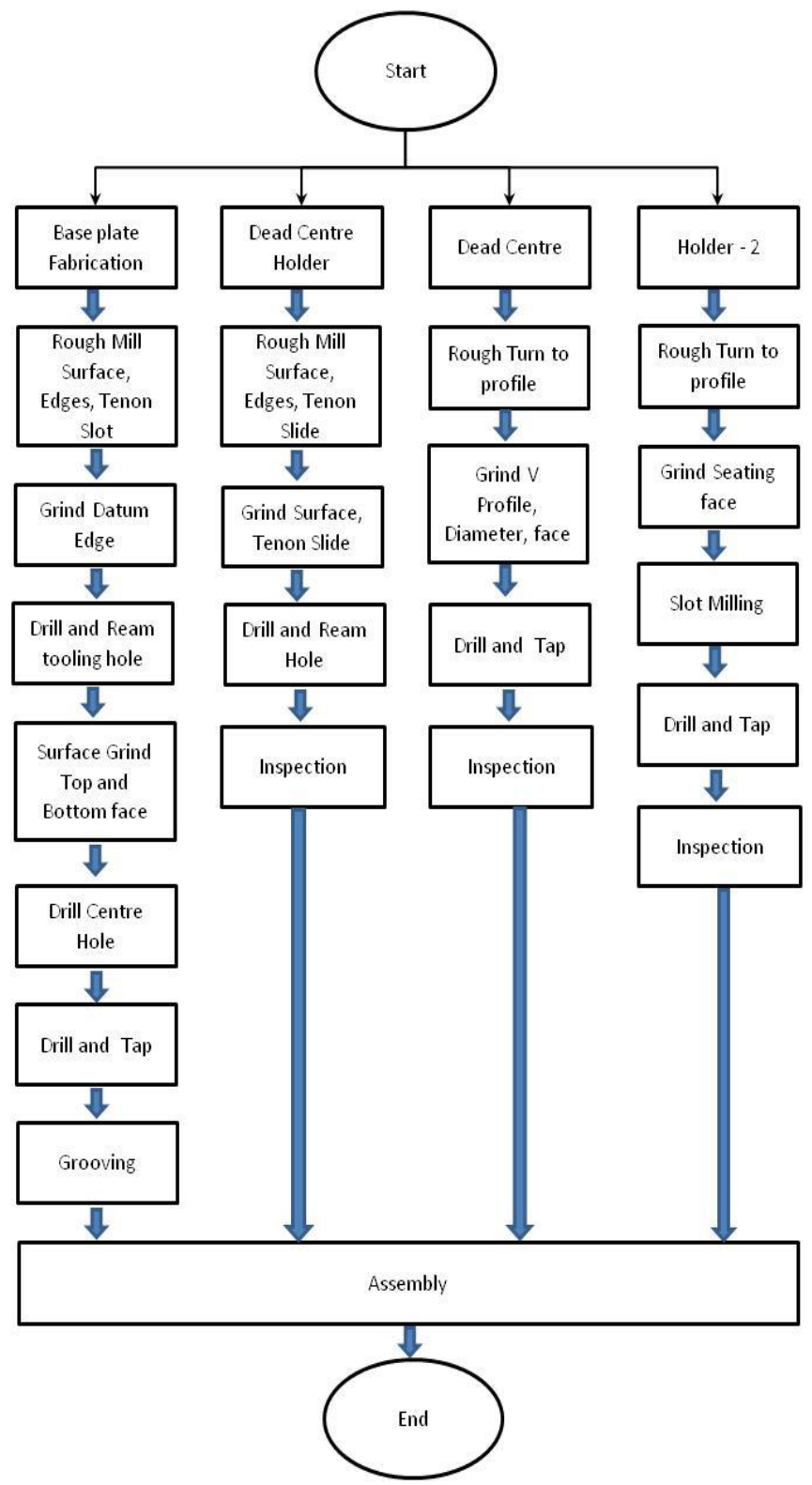

Fig 10: Process Flow Diagram for Crankshaft Component Fixture

\section{IMPLIMENTATION AND USAGE}

This is the phase where the completed product will be handed over to use physically in the work area and the product performance will be measured and monitored. The Product in use should meet the function and specification for which it was designed and fabricated during the design and development phase. Any short fall will be taken as feedback and helps to learn and implement action for upgrade or for next product which will be designed and developed.
As a part of reducing unwanted non value adding activity the usage of modular fixture for all specific components should be standardised hence the same activity will be followed by all resources who are performing the inspection on CMM, this standardisation will yield to follow optimised setup method and reduce the setup time irrespective of resource.

Work instruction is the method used to standardise process of setup, which will instruct the user how exactly the activity to be performed step by step and explains about do's and don'ts of the activity. Sample of work instruction for usage of modular fixture is shown in Fig 11.

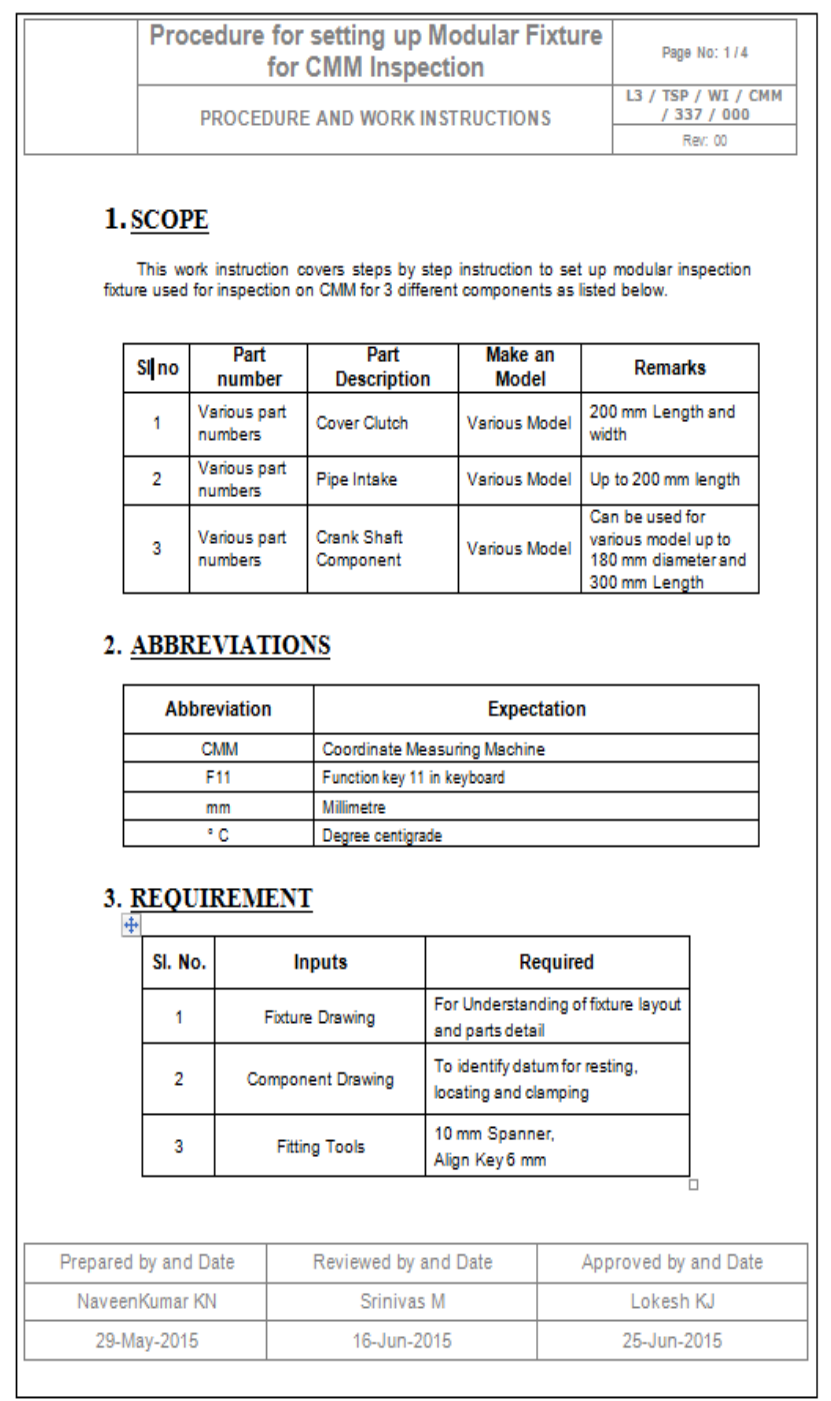

Fig 11: Work Instruction for Assembly procedure Sheet 1 of 4

\section{CONCLUSION}

This project implementation will reduce component inspection setup time on CMM machine by $79 \%$, this reduction of setup time can directly be used for value adding activity like inspection. Use of standardised work instruction will guide inspectors in performing activities which are only required to ensure no non-value adding activities are performed during the process of inspection 
TABLE 1: SETUP TIME STUdY DETAIL AFTER IMPLEMENTATION

\begin{tabular}{|l|l|l|l|l|}
\hline $\begin{array}{l}\text { S1 } \\
\text { no }\end{array}$ & $\begin{array}{l}\text { Component } \\
\text { Name }\end{array}$ & $\begin{array}{l}\text { Avg Set } \\
\text { up time } \\
\text { in mins } \\
\text { before }\end{array}$ & $\begin{array}{l}\text { Avg } \\
\text { Set up } \\
\text { time } \\
\text { in } \\
\text { mins } \\
\text { After }\end{array}$ & $\begin{array}{l}\text { Efficiency } \\
\text { increase }\end{array}$ \\
\hline 1 & Cover clutch & 47 & 11 & $77 \%$ \\
\hline 2 & Pipe intake & 34 & 10 & $71 \%$ \\
\hline 3 & Crank Shaft & 31 & 3.5 & $89 \%$ \\
\hline
\end{tabular}

\section{ACKNOWLEDGMENT}

[1]. I proudly vest my honor to Management of East Point College of Engineering and Technology, Bengaluru for providing me an opportunity to work on this project as part of my research work.

[2]. It gives me immense pleasure to express my deep sense of gratitude to our beloved Dr. B M Satish, Principal, EPCET, whose words of advice have always been a constant source of inspiration for me, and I would like to take this opportunity to thank Dr. R Venkatram, Director, EPCET, Bengaluru.

[3]. I would like to express my heartfelt thanks to Dr. A K Murthy, Head of the Department of Mechanical Engineering, for his valuable advice and encouragement to me in completing this project work.

[4]. I take it as a high esteemed privilege in expressing my sincere gratitude, heartfelt respect and regards to my guide Prof. M S Aswathnarayan, Associate Professor, Department of ME, EPCET, Bengaluru. For the cooperation and support which helped me to accomplish my Project work. Also I am thankful to him for his valuable guidance and innovative ideas given to me during the course of my Project work.

[5]. I would like to thank my parents and friends all of those who supported me in any respect during the project.

\section{REFERENCES}

[1]. Frieder, R., Kumaresan, S., and Sances, A., "Modular medical evacuation fixture for use in military and disaster response vehicles," SAE technical paper 2007-01-1767, 2007, DOI:10.4271/2007-01-1767.

[2]. LI, Y. and Bahr, B., "The design of a flexible fixture for aircraft assembly," SAE technical paper 961885 , 2006, DOI:10.4271/961885

[3]. Moohl, J., "APPLYING jigs and fixtures to engineblock machining," SAE technical paper 250056, 2009, DOI:10.4271/250056.

[4]. BI, Z. M., Zhang, W. J.: Flexible fixture design and automation: review, issues and future directions, international journal of production research, 2010, Vol.39, NO. 13, PP. 2867-2894. 